Brazilian Journal of Animal Science ISSN 1806-9290 www.rbz.org.br
Brasileira de Zootecnia
*Corresponding author:

galileu@ufpa.br

Received: April 5, 2017

Accepted: November 8, 2018

How to cite: Paixão, D. J. M. R.; Brabo, M. F.; Soares, L. M. O.; Campelo, D. A. V. and Veras, G. C. 2019. Optimal feeding frequency for Heros severus (Heckel, 1840), an Amazon ornamental fish. Revista Brasileira de Zootecnia 48:e20170055.

https://doi.org/10.1590/rbz4820170055

Copyright: This is an open access article distributed under the terms of the Creative Commons Attribution License (http://creativecommons.org/licenses/by/4.0/) which permits unrestricted use, distribution, and reproduction in any medium, provided the original work is properly cited.

\section{Optimal feeding frequency for Heros severus (Heckel, 1840), an Amazon ornamental fish}

\author{
Daércio José de Macedo Ribeiro Paixão ${ }^{1}$, Marcos Ferreira Brabo ${ }^{1}$, Lourdes \\ Marília Oliveira Soares ${ }^{1}$, Daniel Abreu Vasconcelos Campelo ${ }^{1}$ iD, Galileu \\ Crovatto $\operatorname{Veras}^{1 *}$ iD \\ ${ }^{1}$ Universidade Federal do Pará, Instituto de Estudos Costeiros, Faculdade de Engenharia de \\ Pesca, Bragança, PA, Brasil.
}

\begin{abstract}
The influence of feeding frequency on growth performance, batch uniformity, and survival rate of severum (Heros severus) larvae and juveniles was investigated in two experiments. In the first, 200 five-day-old severum larvae with $3.20 \pm 0.31 \mathrm{mg}$ and $6.20 \pm 0.39 \mathrm{~mm}$ were randomly distributed into 20 aquaria ( $1 \mathrm{~L}$ ) and fed 500 Artemia nauplii larvae ${ }^{-1}$ day $^{-1}$ for 15 days. In the second, 120 severum juveniles, $178.19 \pm 33.59 \mathrm{mg}$ and $1.82 \pm 0.09 \mathrm{~cm}$, were randomly distributed into 15 aquaria $(300 \mathrm{~L})$ and hand-fed a commercial diet $\left(400.0 \mathrm{~g} \mathrm{~kg}^{-1}\right.$ crude protein and $21.2 \mathrm{~kJ} \mathrm{~g}^{-1}$ gross energy) until apparent satiety for 30 days. For both experiments, feeding frequencies of one, two, three, four, and five meals day ${ }^{-1}$ were evaluated. We used four replicates for the first experiment and three for the second. At the end of both experiments, survival rate and batch uniformity were unaffected by the feeding frequency. Severum larvae fed three, four, and five meals day ${ }^{-1}$ showed higher final weight, weight gain, and specific growth rate, but only the larvae fed five meals day ${ }^{-1}$ showed higher final length and length gain than those fed once and twice day ${ }^{-1}$. Severum juveniles fed two, four, and five meals day ${ }^{-1}$ showed higher final weight, weight gain, and specific growth rate. Growth performance parameters of final length and length gain were not affected by feeding frequencies. Thus, we recommend that the optimal feeding frequency for severum larvae fed Artemia nauplii is three meals day ${ }^{-1}$ and for juvenile severum fed a commercial diet, the optimal frequency is two meals day ${ }^{-1}$.
\end{abstract}

Keywords: Amazon fish, food management, growth performance, nutrition, ornamental fish

\title{
Introduction
}

The practice of cultivating ornamental fish has been growing since the 1980s, with great contributions to world exports. Since 1985, the value of international ornamental trade exports increased at an average of approximately 14\% per year until 1996 (FAO, 2000). In Brazil, the international ornamental fish trade is essentially restricted to the Amazon region (Pelicice and Agostinho, 2005), and wild-caught ornamental fish are potentially one of the few sustainable resources in the Amazon basin (Gerstner et al., 2006). However, due to international pressure to end wild-caught ornamental fishing practices, the commercial cultivation of these fishes has been increasing on the world stage.

Among the species that contribute to the diversity of Amazonian ornamental fauna, severum (Heros severus) has great potential for aquaria life because of its calm behaviour, fast adaptation to new environments, and relatively easy reproduction (Alishahi et al., 2014; Veras et al., 2016). This fish also has a great commercial appeal due to its vibrant olive green to yellow colour with shades of orange 
and red. In its natural environment, it is associated with densely vegetated areas and feeds small invertebrates and plant material (Mérigoux et al., 1998; Alishahi et al., 2014; Veras et al., 2016).

Fish growth is determined by several factors, such as food quality, feeding frequency, feed intake, and the ability to absorb nutrients (Xie et al., 2011). Among these, feeding frequency plays a major role in regulating feed intake and feed waste (Wang et al., 2007; Xie et al., 2011). Most studies have confirmed that there should be an optimal feeding frequency for most fish species, especially in the early life stages (Mollah and Tan, 1982; Xie et al., 2011). Over-feeding increases costs and accumulates waste that adversely affects water quality (Biswas et al., 2006). On the other hand, if fish are fed insufficiently, growth and survival are reduced, and batch uniformity variation is increased (Jobling, 1983; Wang et al., 1998; Lawrence et al., 2012).

The determination of an optimum feeding frequency depends on the fish species, development stage, and culture system (Lee et al., 2000; Cho et al., 2003). This suggests that the effect of feeding frequency on the growth performance of fish should be analysed in detail before practical suggestions are made (Oh and Maran, 2015). Thus, in this study, we aimed to investigate the effects of different feeding frequencies on growth performance in severum larvae and juveniles.

\section{Material and Methods}

The effect of feeding frequency on severum larvae and juveniles was analysed through two consecutive experiments, both conducted in Bragança $\left(01^{\circ} 03^{\prime} 13^{\prime \prime} S\right.$ and $\left.46^{\circ} 45^{\prime} 56^{\prime \prime} \mathrm{W}\right)$, PA, Brazil. Research on animals was conducted according to the institutional committee on animal use (case no. 7656100517).

During the feeding trials of both experiments, water temperature and dissolved oxygen were measured daily with a thermometer and a digital oximeter (Lutron DO -5510, São Paulo, SP, Brazil), respectively. Total ammonia and pH were measured every two days with a multi-parameter meter (HI 3512, Hanna Instruments, Barueri, SP, Brazil). The concentration of unionised ammonia $\left(\mathrm{NH}_{3}\right)$ was calculated using

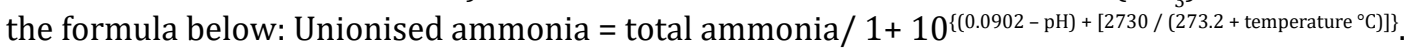

The larvae used in this study were hatched in the laboratory under controlled environmental conditions. Five days after hatching, 200 severum larvae were randomly distributed to 20 1-L aquaria (10 larvae $\mathrm{L}^{-1}$ ). The five different feeding frequencies were randomly assigned and consisted of four replicates of 10 larvae $\mathrm{L}^{-1}$, with a mean initial body weight and length of $3.20 \pm 0.31 \mathrm{mg}$ and $6.20 \pm 0.39 \mathrm{~mm}$ (mean $\pm \mathrm{SD}$ ), respectively.

The feeding frequency treatments were: one meal at 08:00 h, two at 08:00 and 17:00 h, three at 08:00, 12:00, and 16:00 h, four at 08:00, 11:00, 14:00, and 17:00 h, and five at 8:00, 10:00, 12:00, 14:00, and 16:00 h. The severum larvae were fed 500 Artemia nauplii larvae ${ }^{-1}$ day $^{-1}$, for 15 days. Every day, one hour after the last feeding, the aquaria were siphoned to ensure the maintenance of water quality, exchanging one third of the water volume.

For the second experiment, 120 severum juveniles with a mean initial weight and length of $178.19 \pm 33.59 \mathrm{mg}$ and $1.82 \pm 0.09 \mathrm{~cm}(\mathrm{mean} \pm \mathrm{SD})$, respectively, were randomly distributed into 15 300-L aquaria at a density of eight fish aquarium ${ }^{-1}$. A completely randomised design was used, with five treatments and three replicates. During the experimental period, fish in all feeding treatment groups were hand-fed a commercial diet $\left(114.3 \mathrm{~g} \mathrm{~kg}^{-1}\right.$ moisture, $400.0 \mathrm{~g} \mathrm{~kg}^{-1}$ crude protein, $92.4 \mathrm{~g} \mathrm{~kg}^{-1}$ crude lipid, $80.1 \mathrm{~g} \mathrm{~kg}^{-1}$ ash, and $21.2 \mathrm{~kJ} \mathrm{~g}^{-1}$ gross energy) until apparent satiety for 30 days. The feeding schedules were the same as those from the larvae trial. The aquaria were siphoned weekly for water renewal and removal of feces, exchanging one third of the water volume.

At the end of both trials, following $12 \mathrm{~h}$ of starvation, all fish from each aquarium unit were counted and weighed on a precision scale (model MB45 Toledo $^{\circledR} 0.0001 \mathrm{~g}$ ), and their standard lengths were measured with a digital caliper (model series 500 Absolute Coolant Proof ${ }^{\circledR}$ of $0.0001 \mathrm{~m}$ ). Growth performance variables were calculated as follows: weight gain ( $W G=$ final weight - initial weight); specific growth rate $\left(S G R=\left[(\ln\right.\right.$ final weight $-\ln$ initial weight $\left.\left.) \times \Delta \mathrm{t}^{-1}\right] \times 100\right)$; length gain $(\mathrm{LG}=$ final length - initial length); and size uniformity $\left(\mathrm{U}=\left(\mathrm{N} \pm 20 \% \times \mathrm{Nt}^{-1}\right) \times 100\right)$, in which $\mathrm{U}=$ uniformity in 
weight or length; $\pm 20 \%$ = number of animals with weight or length varying $\pm 20 \%$ from the average in each experimental unit; and $\mathrm{Nt}=$ total number of animals within each experimental unit at the end of the experimental period.

The mortality in both experiments was evaluated daily. Individuals were considered dead when spontaneous movements or responses to mechanical stimuli were absent. Any dead fish in the aquaria were removed and counted to calculate the survival rate ( $\mathrm{SR}=$ (final number of animals / initial number of animals) $\times 100$ ).

Results were given as mean \pm SD. The data for both experiments were subjected to Shapiro-Wilk and Levene tests to verify the normality of errors and the homogeneity of variances, respectively. After this, data from each experiment were subjected to one-way analysis of variance (ANOVA) followed by Tukey's test $(\mathrm{P}<0.05)$, to compare the means when differences occurred. The uniformity of larval and juvenile length and juvenile survival did not appear normal, even after transformation. Therefore, for these variables, a Kurskal Wallis test was employed. All statistical analyses were performed with Statistica 8.0 for Windows (Stat Soft 2004). The statistical model that represents the completely randomised experimental design is presented as follows:

$$
Y_{(i)(j)}=\mu+t_{(i)}+e_{(i)(j)}
$$

in which (i) is the number of treatment levels; (j) is the number of replicates; $Y_{(i)(j)}$ is the value of the variable tested under the given treatment level; $\mu$ is the overall average of the experiment for the analysed variable; $t_{(i)}$ is the effect of a determined level of treatment; and $e_{(i)(j)}$ is the random error.

\section{Results}

There was no effect of feeding frequency on the water quality variables $(\mathrm{P}>0.05)$ in both experiments (Table 1).

There was no influence of feeding frequency on survival rate and on weight and length uniformity of severum larvae $(P>0.05)$. However, the growth performance was affected by feeding frequency $(P<0.05)$. Severum larvae fed three, four, and five meals day ${ }^{-1}$ showed higher final weight, weight gain, and specific growth rate than those fed once and twice day ${ }^{-1}$. The same was observed for the final length and length gain, but fish fed five meals day ${ }^{-1}$ were not significantly longer than fish fed three and four meals day ${ }^{-1}$ (Table 2).

Survival rate, weight and length uniformity, final length, and length gain of severum juveniles were not affected $(\mathrm{P}>0.05)$ by the different feeding frequencies. On the other hand, final weight, weight gain, and specific growth rate were higher $(\mathrm{P}<0.05)$ for fish fed two, four, and five meals $\mathrm{day}^{-1}$ than those fed one and three meals day ${ }^{-1}$ (Table 3 ).

Table 1 - Water quality variables of Heros severus larvae and juveniles fed at different feeding frequencies

\begin{tabular}{lccccc}
\hline Feeding frequency $\left(\right.$ meals day $\left.^{-1}\right)$ & Life stage & Temperature $\left({ }^{\circ} \mathrm{C}\right)$ & DO $\left(\mathrm{mg} \mathrm{L}^{-1}\right)$ & $\mathrm{pH}$ & $\mathrm{UA}\left(\mathrm{mg} \mathrm{L}^{-1}\right)$ \\
\hline \multirow{2}{*}{ One } & Larva & $28.13 \pm 0.47$ & $6.78 \pm 0.18$ & $6.16 \pm 0.17$ & $0.0018 \pm 0.0013$ \\
& Juvenile & $28.80 \pm 0.17$ & $7.21 \pm 0.06$ & $6.29 \pm 0.35$ & $0.0018 \pm 0.0011$ \\
Two & Larva & $28.51 \pm 0.37$ & $6.79 \pm 1.41$ & $6.17 \pm 0.13$ & $0.0023 \pm 0.0011$ \\
& Juvenile & $28.90 \pm 0.15$ & $7.24 \pm 0.06$ & $6.21 \pm 0.16$ & $0.0019 \pm 0.0012$ \\
Three & Larva & $28.37 \pm 0.17$ & $6.74 \pm 1.59$ & $6.10 \pm 0.22$ & $0.0024 \pm 0.0014$ \\
& Juvenile & $28.70 \pm 0.35$ & $7.25 \pm 0.06$ & $6.17 \pm 0.16$ & $0.0019 \pm 0.0008$ \\
Four & Larva & $28.61 \pm 0.34$ & $6.74 \pm 1.86$ & $6.11 \pm 0.16$ & $0.0019 \pm 0.0009$ \\
& Juvenile & $28.60 \pm 0.46$ & $7.18 \pm 0.15$ & $6.15 \pm 0.18$ & $0.0018 \pm 0.0006$ \\
Five & Larva & $28.23 \pm 0.72$ & $6.73 \pm 2.02$ & $6.15 \pm 0.16$ & $0.0018 \pm 0.0009$ \\
& Juvenile & $28.70 \pm 0.31$ & $7.15 \pm 0.010$ & $6.18 \pm 0.18$ & $0.0017 \pm 0.0005$ \\
P-value & Larva & 0.2328 & 0.9694 & 0.8588 & 0.1895 \\
& Juvenile & 0.2851 & 0.8664 & 0.9449 & 0.9876 \\
\hline
\end{tabular}

DO - dissolved oxygen; UA - unionised ammonia. 
Table 2 - Performance of Heros severus larvae fed at five different feeding frequencies for 15 days

\begin{tabular}{lcccccc}
\hline \multirow{2}{*}{ Variable } & \multicolumn{5}{c}{ Feeding frequency (meals day ${ }^{-1}$ ) } & P-value \\
\cline { 2 - 6 } & One & Two & Three & Four & Five & \\
\hline FW (mg) & $43.78 \pm 1.14 \mathrm{~b}$ & $49.19 \pm 7.05 \mathrm{~b}$ & $60.33 \pm 2.20 \mathrm{a}$ & $62.42 \pm 4.65 \mathrm{a}$ & $59.33 \pm 4.60 \mathrm{a}$ & 0.0001 \\
WG (mg) & $40.58 \pm 1.14 \mathrm{~b}$ & $45.99 \pm 7.05 \mathrm{~b}$ & $57.13 \pm 2.20 \mathrm{a}$ & $59.22 \pm 4.65 \mathrm{a}$ & $56.13 \pm 4.60 \mathrm{a}$ & 0.0001 \\
SGR (\% day ${ }^{-1}$ ) & $17.44 \pm 0.17 \mathrm{~b}$ & $18.17 \pm 0.92 \mathrm{~b}$ & $19.57 \pm 0.24 \mathrm{a}$ & $19.79 \pm 0.50 \mathrm{a}$ & $19.45 \pm 0.52 \mathrm{a}$ & 0.0000 \\
FL (mm) & $14.48 \pm 0.20 \mathrm{~b}$ & $14.67 \pm 0.62 \mathrm{~b}$ & $15.12 \pm 0.27 \mathrm{ab}$ & $15.37 \pm 0.55 \mathrm{ab}$ & $16.00 \pm 0.26 \mathrm{a}$ & 0.0009 \\
LG (mm) & $8.28 \pm 0.20 \mathrm{~b}$ & $8.47 \pm 0.62 \mathrm{~b}$ & $8.92 \pm 0.27 \mathrm{ab}$ & $9.17 \pm 0.55 \mathrm{ab}$ & $9.80 \pm 0.26 \mathrm{a}$ & 0.0009 \\
UW (\%) & $70.00 \pm 14.00 \mathrm{a}$ & $75.00 \pm 10.00 \mathrm{a}$ & $89.00 \pm 8.00 \mathrm{a}$ & $79.00 \pm 19.00 \mathrm{a}$ & $88.00 \pm 12.00 \mathrm{a}$ & 0.1622 \\
UL (\%) & $100.00 \pm 0.00 \mathrm{a}$ & $100.00 \pm 0.00 \mathrm{a}$ & $100.00 \pm 0.00 \mathrm{a}$ & $98.00 \pm 0.05 \mathrm{a}$ & $100.00 \pm 0.00 \mathrm{a}$ & 0.4380 \\
SR (\%) & $98.00 \pm 5.00 \mathrm{a}$ & $100.00 \pm 0.00 \mathrm{a}$ & $92.50 \pm 10.00 \mathrm{a}$ & $93.00 \pm 10.00 \mathrm{a}$ & $90.00 \pm 14.00 \mathrm{a}$ & 0.5286 \\
\hline
\end{tabular}

FW - final weight; WG - weight gain; SGR - specific growth rate; FL - final length; LG - length gain; UW - uniformity of weight; UL - uniformity of length; SR - survival rate.

Values $($ mean $\pm S D ; n=4)$ in the same row followed by different letters are different by the Tukey test $(\mathrm{P}<0.05)$.

Table 3 - Performance of Heros severus juveniles fed at five different feeding frequencies for 30 days

\begin{tabular}{lcccccc}
\hline \multirow{2}{*}{ Variable } & \multicolumn{5}{c}{ Feeding frequency (meals day ${ }^{-1}$ ) } & P-value \\
\cline { 2 - 6 } & One & Two & Three & Four & Five & \\
\hline FW (mg) & $576.36 \pm 30.30 \mathrm{~b}$ & $700.66 \pm 7.24 \mathrm{a}$ & $642.61 \pm 9.43 \mathrm{~b}$ & $685.40 \pm 60.04 \mathrm{a}$ & $663.92 \pm 10.66 \mathrm{a}$ & 0.0049 \\
WG (mg) & $398.16 \pm 30.30 \mathrm{~b}$ & $522.46 \pm 7.24 \mathrm{a}$ & $464.41 \pm 9.43 \mathrm{~b}$ & $507.20 \pm 60.04 \mathrm{a}$ & $485.72 \pm 10.66 \mathrm{a}$ & 0.0001 \\
SGR (\% day ${ }^{-1}$ ) & $7.82 \pm 0.35 \mathrm{~b}$ & $9.13 \pm 0.07 \mathrm{a}$ & $8.55 \pm 0.10 \mathrm{~b}$ & $8.96 \pm 0.57 \mathrm{a}$ & $8.77 \pm 0.11 \mathrm{a}$ & 0.0034 \\
FL (mm) & $23.78 \pm 0.21 \mathrm{a}$ & $24.89 \pm 1.19 \mathrm{a}$ & $24.48 \pm 0.24 \mathrm{a}$ & $24.48 \pm 0.35 \mathrm{a}$ & $24.00 \pm 0.20 \mathrm{a}$ & 0.2174 \\
LG (mm) & $5.58 \pm 0.21 \mathrm{a}$ & $6.69 \pm 1.19 \mathrm{a}$ & $6.28 \pm 0.24 \mathrm{a}$ & $6.28 \pm 0.35 \mathrm{a}$ & $5.80 \pm 0.20 \mathrm{a}$ & 0.2174 \\
UW (\%) & $88.00 \pm 13.00 \mathrm{a}$ & $86.00 \pm 14.00 \mathrm{a}$ & $79.00 \pm 19.00 \mathrm{a}$ & $96.00 \pm 7.00 \mathrm{a}$ & $83.00 \pm 14.00 \mathrm{a}$ & 0.6858 \\
UL (\%) & 100.00 & 100.00 & 100.00 & 100.00 & 100.00 & - \\
SR (\%) & $100.00 \pm 0.00 \mathrm{a}$ & $96.00 \pm 7.00 \mathrm{a}$ & $100.00 \pm 0.00 \mathrm{a}$ & $100.00 \pm 0.00 \mathrm{a}$ & $100.00 \pm 0.00 \mathrm{a}$ & 0.4516 \\
\hline
\end{tabular}

FW - final weight; WG - weight gain; SGR - specific growth rate; FL - final length; LG - length gain; UW - uniformity of weight; UL - uniformity of length; SR - survival rate.

Values (mean $\pm \mathrm{SD} ; \mathrm{n}=3$ ) in the same row followed by different letters are different by the Tukey test $(\mathrm{P}<0.05)$.

\section{Discussion}

Regardless of the feed frequency used, the results of water quality parameters remained within that recommended for the species, which is similar to a study with H. severus larvae (Veras et al., 2016). These results confirm that the storage density and management used in the feeding and cleaning of the experimental units were efficient and did not damage the water quality parameters.

The initial stages of the fish life cycle are considered the most critical in the production system. For many fish species, increasing feeding frequency has been demonstrated to reduce mortality, control size variation, and reduce the stress and labour costs related to grading (Wang et al., 1998; Dou et al., 2000; Costa-Bomfim et al., 2014). However, in the present study, survival rate and size uniformity of severum larvae and juveniles were not affected by feeding frequency. Increased mortality and size variations are induced by competition or hierarchy behavior, which are more accentuated when there is significant size heterogeneity among fish (Hayashi et al., 2004; Baloi et al., 2016). The small ranges of variation in the initial body weights and lengths of severum larvae and juveniles, in addition to the adequate stocking density, may explain the lack of influence of feeding frequency on the survival rate and batch uniformity of fish. In addition, the survival results observed in the present study can also be explained by the high quality of the feed offered in the two stages of fish life, even when the feed was offered at a reduced frequency. 
In the present study, severum larvae fed three meals day ${ }^{-1}$ had growth performance similar to larvae fed four and five meals day ${ }^{-1}$, and yet displayed significantly higher growth than those fed one and two meals day ${ }^{-1}$. This suggests that the appropriate feeding frequency is advantageous to growth and development of fish larvae. Larvae may have more opportunities to obtain enough feed at higher feeding frequencies than at lower feeding frequencies, leading to a higher growth rate (Xie et al., 2011). In a similar study, hybrid sunfish larvae (Lepomis cyanellus $\times$ L. macrochirus), fed to satiation three and four times daily, showed significantly greater weight gain and specific growth rates than fish fed once daily (Wang et al., 1998). Moreover, specific growth rates of large yellow croaker (Pseudosciaena crocea) larvae, fed two or four meals day ${ }^{-1}$, were significantly lower than those fed eight and twelve meals day ${ }^{-1}$ (Xie et al., 2011).

The effects of feeding frequency on fish growth are also related to the size of the stomach and intestines. Therefore, feeding frequency is also related to gastric evacuation time (Riche et al., 2004). Species with larger stomachs require lower feeding frequencies to achieve maximum growth (Pillay and Kutty, 2005), since the gastric evacuation time will be longer. Feeding at intervals shorter than the time required for the return of appetite can lead to gastric overload, resulting in reduced nutrient absorption efficiency. On the other hand, two or more meals are usually recommended for omnivorous fish (Pannevis and Earle, 1994; Wang et al., 1998; Dwyer et al., 2002), which have smaller stomachs and longer intestines compared to carnivorous fish (Costa-Bomfim et al., 2014) and, therefore, present rapid gastric emptying, as shown in a study with Nile tilapia (Riche et al., 2004). Larvae have not completed their digestive system formation and normally need higher feeding frequencies. However, after the complete development of the digestive system, in the fingerling and juvenile life stages, the feeding frequency can be reduced.

Although the digestive capacity of fish is lower in the initial stages of development, growth rate is higher than those observed in other life phases (Xie et al., 2011). Therefore, a greater number of daily meals may promote better growth for larvae and fingerlings, since there is a constant need of nutrient supply for the development of these individuals. On the other hand, an exaggerated number of meals can reduce the amount of food offered during each feeding period, which may create more disputes and hamper the development of these organisms (Hayashi et al., 2004). A high feeding frequency may also decrease the passage time of the feed in the gastrointestinal tract, which can negatively affect the activity of the digestive enzymes and, consequently, the performance of the fish, promoting a higher excretion. A high feeding frequency can also lead to an increase in production costs due to a greater need for labor and greater waste of food, which is one of the most expensive items in aquaculture (Biswas et al., 2006; Zeytin et al., 2016).

As feed is the single most significant cost involved in aquaculture operations, there is emphasis on carrying out farming by considering the maximum feed conversion into fish growth (Baloi et al., 2016). This contributes to a more economical and environmentally friendly production, since over-feeding increases costs and nitrogen waste. Nitrogen waste production in fish farms is directly affected by the feeding regime (Azevedo et al., 1998), which has an inverse correlation with feed utilisation by fish and can be minimised by regulating feeding frequency (Wang et al., 2007). However, the different feeding frequencies tested in experiments with severum did not influence water quality. It is likely that the water quality variables remained within the recommended range for the species, regardless of the feeding frequency tested, since the partial water changes were carried out daily and there was caution to not waste food. Therefore, it may be possible to reduce feeding frequency for severum larvae and juveniles without adversely affecting growth performance, size uniformity, or survival rate, thereby improving profitability through decreased labour costs.

\section{Conclusions}

The results of the present study suggest that three meals day ${ }^{-1}$ is the optimum feeding frequency for severum larvae cultured with Artemia nauplii and two meals day ${ }^{-1}$ is the optimum feeding frequency for severum juveniles.

R. Bras. Zootec., 48:e20170055, 2019 


\section{Acknowledgments}

The authors thank the Conselho Nacional de Desenvolvimento Científico e Tecnológico (CNPq), Coordenação de Aperfeiçoamento de Pessoal de Nível Superior (CAPES), and Pró-Reitoria de Pesquisa e Pós-Graduação of the Universidade Federal do Pará, for financial support.

\section{References}

Alishahi, M.; Karamifar, M.; Mesbah, M. and Zarei, M. 2014. Hemato-immunological responses of Heros severus fed diets supplemented with different levels of Dunaliella salina. Fish Physiology and Biochemistry 40:57-65. https://doi.org/10.1007/s10695-013-9823-5

Azevedo, P. A.; Cho, C. Y.; Leeson, S. and Bureau, D. P. 1998. Effects of feeding level and water temperature on growth, nutrient and energy utilization and waste output of rainbow trout (Oncorhynchus mykiss). Aquatic Living Resources 11:227-238. https://doi.org/10.1016/S0990-7440(98)89005-0

Baloi, M.; Carvalho, C. V. A.; Sterzelecki, F. C.; Passini, G. and Cerqueira, V. R. 2016. Effects of feeding frequency on growth, feed efficiency and body composition of juveniles Brazilian sardine, Sardinella brasiliensis (Steindacher 1879). Aquaculture Research 47:554-560. https://doi.org/10.1111/are.12514

Biswas, G.; Jena, J. K.; Singh, S. K.; Patmajhi, P. and Muduli, H. K. 2006. Effect of feeding frequency on growth, survival and feed utilization in mrigal, Cirrhinus mrigala, and rohu, Labeo rohita, during nursery rearing. Aquaculture 254:211-218. https://doi.org/10.1016/j.aquaculture.2005.08.001

Cho, S. H.; Lim, Y. S.; Lee, J. H.; Lee, J. K.; Park, S. and Lee, S. M. 2003. Effect of feeding rate and feeding frequency on survival, growth, and body composition of ayu post-larvae Plecoglossus altivelis. Journal of the World Aquaculture Society 34:85-91. https://doi.org/10.1111/j.1749-7345.2003.tb00042.x

Costa-Bomfim, C. N.; Pessoa, W. V. N.; Oliveira, R. L. M.; Farias, J. L.; Domingues, E. C.; Hamilton, S. and Cavalli, R. O. 2014. The effect of feeding frequency on growth performance of juvenile cobia, Rachycentron canadum (Linnaeus, 1766). Journal of Applied Ichthyology 30:135-139. https://doi.org/10.1111/jai.12339

Dou, S.; Seikai, T. and Tsukamoto, K. 2000. Cannibalism in Japanese flounder juveniles, Paralichthys olivaceus, reared under controlled conditions. Aquaculture 182:149-159. https://doi.org/10.1016/S0044-8486(99)00256-2

Dwyer, K. S.; Brown, J. A.; Parrish, C. and Lall, S. P. 2002. Feeding frequency affects food consumption, feeding pattern and growth of juvenile yellowtail flounder (Limanda ferruginea). Aquaculture 213:279-292. https://doi.org/10.1016/ S0044-8486(02)00224-7

FAO - Food and Agriculture Organization of the United Nations. 2000. FAO Aquaculture Newsletter (FAN) No.24. Available at: <http://www.fao.org/tempref/docrep/fao/005/x4933e/x4933e00.pdf>. Accessed on: Mar. 08, 2019.

Gerstner, C. L.; Ortega, H.; Sanchez, H. and Graham, D. L. 2006. Effects of the freshwater aquarium trade on wild fish populations in differentially-fished areas of the Peruvian Amazon. Journal of Fish Biology 68:862-875. https://doi. org/10.1111/j.0022-1112.2006.00978.x

Hayashi, C.; Meurer, F.; Boscolo, W. R.; Lacerda, C. H. F. and Kavata, L. C. B. 2004. Frequência de arraçoamento para alevinos de lambari do rabo-amarelo (Astyanax bimaculatus). Revista Brasileira de Zootecnia 33:21-26. https://doi.org/10.1590/ S1516-35982004000100004

Jobling, M. 1983. Effect of feeding frequency on food intake and growth of Arctic charr, Salvelinus alpinus L. Journal of Fish Biology 23:177-185.

Lawrence, C.; Best, J.; James, A. and Maloney, K. 2012. The effects of feeding frequency on growth and reproduction in zebrafish (Danio rerio). Aquaculture 368-369:103-108. https://doi.org/10.1016/j.aquaculture.2012.09.022

Lee, S. M.; Hwang, U. G. and Cho, S. H. 2000. Effects of feeding frequency and dietary moisture content on growth, body composition and gastric evacuation of juvenile Korean rockfish (Sebastes schlegeli). Aquaculture 187:399-409. https://doi.org/10.1016/S0044-8486(00)00318-5

Mérigoux, S.; Ponton, D. and Mérona, B. 1998. Fish richness and species-habitat relationships in two coastal streams of French Guiana, South America. Environmental Biology of Fishes 51:25-39. https://doi.org/10.1023/A:1007422100976

Mollah, M. F. A. and Tan, E. S. P. 1982. Effects of feeding frequency on the growth and survival of catfish (Clarias macrocephalus Gunther) larvae. Indian Journal of Fisheries 29:1-7.

Oh, S. Y. and Maran, B. A. V. 2015. Feeding frequency influences growth, feed consumption and body composition of juvenile rock bream (Oplegnathus fasciatus). Aquaculture International 23:175-184. https://doi.org/10.1007/s10499014-9806-2

Pannevis, M. C. and Earle, K. E. 1994. Nutrition of ornamental fish: water soluble vitamin leaching and growth of Paracheirodon innesi. Journal of Nutrition 124:2633-2635. https://doi.org/10.1093/jn/124.suppl_12.2633S 
Pelicice, F. M. and Agostinho, A. A. 2005. Perspectives on ornamental fisheries in the upper Paraná River floodplain, Brazil. Fisheries Research 72:109-119. https://doi.org/10.1016/j.fishres.2004.09.005

Pillay, T. V. R. and Kutty, M. N. 2005. Aquaculture: principles and practices. 2nd ed. Blackwell Publishing, Oxford.

Riche, M.; Haley, D. I.; Oetker, M.; Garbrecht, S. and Garling, D. L. 2004. Effect of feeding frequency on gastric evacuation and the return of appetite in tilapia Oreochromis niloticus (L.). Aquaculture 234:657-673. https://doi.org/10.1016/j. aquaculture.2003.12.012

Veras, G. C.; Paixão, D. J. M. R.; Brabo, M. F.; Soares, L. M. O. and Sales, A. D. 2016. Influence of photoperiod on growth, uniformity and survival of the larvae of the Amazonian ornamental Heros severos (Heckel, 1840). Revista Brasileira de Zootecnia 45:422-426. https://doi.org/10.1590/S1806-92902016000700010

Wang, N.; Hayward, R. S. and Noltie, D. B. 1998. Effect of feeding frequency on food consumption, growth, size variation, and feeding pattern of age-0 hybrid sunfish. Aquaculture 165:261-267. https://doi.org/10.1016/S0044-8486(98)00266-X

Wang, Y.; Kong, L. J.; Li, K. and Bureau, D. P. 2007. Effects of feeding frequency and ration level on growth, feed utilization and nitrogen waste output of cuneate drum (Nibea miichthioides) reared in net pens. Aquaculture 271:350-356. https://doi.org/10.1016/j.aquaculture.2007.03.022

Xie, F.; Ai, Q.; Mai, K.; Xu, W. and Ma, H. 2011. The optimal feeding frequency of large yellow croaker (Pseudosciaena crocea, Richardson) larvae. Aquaculture 311:162-167. https://doi.org/10.1016/j.aquaculture.2010.12.005

Zeytin, S.; Schulz, C. and Ueberschär, B. 2016. Diurnal patterns of tryptic enzyme activity under different feeding regimes in gilthead sea bream (Sparus aurata) larvae. Aquaculture 457:85-90. https://doi.org/10.1016/j.aquaculture.2016.02.017 